\title{
TEKS PELAJARAN SISWA SEKOLAH DASAR (SD) KELAS IV KURIKULUM 2013: KAJIAN BERDASARKAN LINGUISTIK FUNGSIONAL SISTEMIK
}

\author{
Sri Sugiarto ${ }^{1}$ \\ Programstudi Pendidikan Bahasa dan Sastra Indonesia Universitas Samawa \\ srisugiarto@universitassamawa.ac.id
}

\begin{abstract}
ABSTRAK
Teks pelajaran memiliki peran dalam kegiatan pembelajaran, salah satunya untuk mempermudah siswa menuntaskan kompetensi dasar yang telah disusun dalam kurikulum 2013. Berkaitan hal tersebut topik penelitian ini, yakni kajian teks pelajaran siswa SD kelas IV dalam kurkulum 2013. Rumusan masalahanya, (a) bagaimanakah wujud unsur transitivitas teks dalam materi buku teks pelajaran siswa SD kelas IV dalam kurikulum 2013? (b) bagaimanakah pola pengembangan TemaRema teks dalam materi buku teks pelajaran siswa SD kelas IV dalan kurikulum 2013?, dan (3) bagaimanakan relevansi isi teks dalam materi buku teks pelajaran siswa SD kelas IV dengan materi kurikulum 2013?. Penelitian ini menggunakan teori LFS yang dikemukakan oleh Halliday (1994 dan 2004) yang dipadukan dengan cara pengembangan bahan ajar tematik yang dikemukan oleh Prastwo (2012). Pendekatan yang digunakan dalam penelitian ini menggunakan pendekatan kualitatif. Berdasarkan hasil penganalisisan dan pembahasan, dapat dikemukakan bahwa unsur transitivitas teks pembelajaran pada buku bertema "indahnya kebersamaan", "berhemat energi", "peduli terhadap mahluk hidup", dan "berbagai pekerjaan" didominansi oleh proses material. Unsur partisipannya didominansi oleh partisipan Pelaku dan Gol. Selanjunya, unsur sirkumstan pada buku bertema "indahanya kebersamaan" dan "peduli terhadap lingkungan" didominansi oleh sirkusmstan tempat, buku bertema "berhemat energi" didominansi oleh sikrumstan cara, sedangkan buku bertema "berbagai pekerjaan" didominansi oleh sirkumstan waktu. Pola pengembangan Tema-Rema menggunakan pola tema Zig-zag, pola tetap, dan pola tema gabung. Terakhir terkait dengan kerelevansian teks, keempat buku ini perlu dilakukan perevisian karena banyak ditemukan teks pelajaran yang tidak relevan dengan kompentesi dasar yang ada di dalam kurikulum 2013.
\end{abstract}

Kata kunci: teks pelajaran, linguistik fungsional sistemik, transitivitas, pola pengembangan Tema-Rema, relevansi

\section{PENDAHULUAN}

Buku teks pelajaran merupakan suatu penjabaran unsur pengalaman non-linguistik yang berupa konteks sosial yang diwujudkan dengan pengalaman linguistik dalam sebuah teks serta disusun secara sistematis dengan tujuan untuk mencapai tujuan insturksional pendidikan yang didasari oleh kurikulum yang berlaku. Buku jenis ini tidak bisa dipisahkan dengan dunia pendidikan. Hal ini dikarenakan fungsi buku teks pelajaran memiliki peranan bagi siswa. Salah satu peranan bagi siswa, yaitu dijadikan sebagai media dan bahan belajar secara mandiri baik di dalam kelas maupun di luar kelas.

Penyusunan buku teks pelajaran yang digunakan oleh siswa, disusun berorientasi pada kurikulum yang sedang 
diterapkan di sekolah. Kurikulum pendidikan dewasa ini yang ditarapkan dalam pendidikan di Indonesia adalah kurikulum 2013. Penyusunan buku teks dalam kurikulum ini khususnya untuk kelas IV sekolah dasar (SD) menggunakan pendekatan tematik yang muliti disipliner. Selain itu pula, pengemasan materi pembelajaran berbasis teks.

Beberapa media masa dan pengamat pendidikan menyoroti teks pelajaran yang dijadikan materi di dalam buku teks pelajaran pegangan siswa ini masih memiliki permasalahan. Beberapa permasalahannya, yaitu (1) terdapat pemilihan istilah yang kurang tepat, (2) waktu penyusunan yang relatif singkat, sehingga ada beberapa teks yang tidak memiliki relavansi dengan KD yang harus dicapai oleh siswa. Maka dengan adanya beberapa permasalahan ini, teks pelajaran yang ada di dalam buku teks pelajaran perlu dilihat dan dikaji.

Berdasarkan masalah di atas, buku teks pelajaran ini sangat perlu ditinjau dari aspek kelinguistikan karena setiap teks memiliki ciri linguistik dan fakta sosial yang berbeda-beda. Hal ini dapat dilihat dari struktur dan tekstur yang membangun teks tersebut. Persoalan bagaimana wujud unsur entitas yang membangun sebuah teks pelajaran, bagaimana pola pengembangan Tema-Rema teks pelajaran, dan bagaimana kerelevansian isi teks dengan KD yang harus dicapai oleh siswa dapat dianalisis dengan menggunakan pendekatan linguisitik fungsional sistemik (LFS). Pendekatan ini terbukti mampu manjawab berbagai persoalan kebahasaan terkait dengan pendidikan bahasa terutama materi pembelajaran yang digunakan dalam kegiatan pembelajaran, (bandingkan: Eggins, 2004: 3).

Dalam teori LFS bahasa dipandang memiliki tiga fungsi, yaitu fungsi ideasional, interpersonal, dan kontekstual. Ketiga fungsi ini sering disebut dengan metafungsi bahasa. Halliday (2004:169) menjelaskan ketiga fungsi bahasa tersebut, yakni fungsi tekstual direalisasikan oleh sistem Tema dan Rema (theme-rheme), fungsi interpersonal direalisasikan oleh sistem mode dan residu, fungsi ideasional terdiri atas fungsi. Fungsi tekstual bahasa diwujudkan ke dalam Tema dan Rema, (Halliday, 2004: 64 \& Arunsirot, 2013: 163). Tema adalah titik awal pesan (the starting point of the message) di dalam klausa. Rema adalah sisa pesan (the rest of the message) setelah tema. Hal ini berarti bahwa satu klausa terdiri atas Tema, yakni titik mula pesan. Rema, yakni pesan dalam bagian klausa selanjutnya (Saragih, 2010: 6). Selanjutnya, pola pengembangan tema adalah kecenderungan dalam keteraturan berlangsungnya suatu proses. Pola pengembangan tema diusulkan Eggin (2004) ada tiga, yaitu pola zig-zig, pola tetap, dan pola gabungan. Terakhir, fungsi ideasional merupakan realisasi pengalaman yang disajikan dalam teks pelajaran disebut dengan transitivitas. Transitivitas suatu pesan yang lengkapnya biasanya direalisasikan dengan tiga unsur penting transitivitas, yaitu proses, partisipan, dan sirkumstan (Halliday, 2004:170 dan Butt, 2003: 66).

\section{METODE PENELITIAN}

Pendekatan dalam penelitian ini bersifat kualitatif. Dengan tujuan sebagai upaya pendeskripsian fenomena kebahasaan dalam pengembangan materi buku teks pelajaran yang digunakan pada kurikulum 2013. Selanjutnya, pendekatan linguistik yang akan digunakan sebagai upaya menjawab permasalahan dalam penelitian ini, yaitu pendekatan LFS.

Buku teks pelajaran yang dijadikan sebagai data analisis diambil dari keempat buku teks pelajaran yang diterbitkan oleh Kemendikbut. Buku tersebut, yakni Indahnya Kebersamaan (T1) Selalu 
Berhemat Energi (T2) Peduli Terhadap Mahluk Hidup (T3) Berbagai Perkerjaan (T4).

$\begin{array}{rlcr}\text { Metode } & \text { yang digunakan dalam } \\ \text { pengumpulan } & \text { data, yaitu metode }\end{array}$
dokumentasi. Dalam penelitian kualitatif, metode dokumentasi digunakan untuk pengumpulan data yang berupa sumber tertulis seperti buku teks, dokumen pribadi, dokumen resmi, majalah, dan lain sebagainya, (bandingkan dengan, Denzin \& Lincoln, 2009: 543; Moleong, 2013: 159). Teknik baca digunakan sebagai upaya pencermatan data-data yang digunakan untuk menjawab permasalahan dalam penelitian (bandingkan, Ratna, 2012: 245). Penganalisisan data sebagai upaya yang dilakukan dengan jalan bekerja dengan data, pengorganisasian data, pemilahan data dengan tujuan penulisan ditarik maknanya, dan pada akhirnya menarik sebuah makna dari data, (bandingkan: Miles dan Huberman, 1992: 16).

\section{HASIL DAN PEMBAHASAN}

\section{Wujud Unsur Transitivitas Teks Pelajaran}

Transitivitas terkait dengan proses, partisipan, dan sirkumstan. Berikut ini diuraikan hasil analisis transitivitas dari keempat buku teks pelajaran.

\section{Unsur Proses}

Dalam presfektif LFS proses material dimaknai sebagai aktivitas atau kegiatan yang menyangkut fisik dan nyata dilakukan pelakunya. Karena sifatnya yang demikian proses material dapat diamati dengan indera. Jadi, dapat dipahami fungsi teks yang ada di dalam keempat buku tersebut lebih menekankan kepada perkembangan fisikomotirk anak. Artinya, segala kegiatan di dalam teks tersebut lebih menuntut siswa untuk lebih aktif dan kreatif.
Perkembangan kognitif pada usia SD kelas IV dalam teori perkembangan kognitif anak memasuki pada tingkat operasional yang bersifat kongkret dan logis. Artinya, semua hal yang dilakukan harus bersifat nyata dan dapat dilihat dan ditiru. Oleh karean itu, teks pelajaran yang digunakan dalam pembelajaran harus mencerminkan hal-hal yang bersifat kongkret.

Berkaitan hal tersebut, jika dilihat unsur trasntivitas yang ada di dalam teks plejaran yang dijadikan sebagai materi pelajaran pada siswa SD kelas IV lebih didominansi oleh proses material sebanyak 161 kalusa atau 54,03\% . Hal ini menunjukkan teks pembelajaran ini lebih menekankan pada hal-hal yang bersifat kongkret. Maka teks pelajaran yang terdapat di dalam buku teks ini dapat dikatakan dapat digunakan untuk meningkatkan perkembangan kognitif siswa pada anak SD kelas IV.

Teks pembelajaran ini lebih memfasilitasi pekembangan motorik atau keterampilan siswa, hal ini dapat dibuktikan dengan adanya proses material yang mendominansi. Proses ini dapat ditemukan pada teks pelajaran yang menjelasakan gerakan kesenian tari tradisional, permainan tradisional, prosedur membuat kesenian. Jadi, jelas teks pelajaran di dalam buku ini lebih menekankan pada aspek psikomotorik anak.

Tabel 1. Unsur Proses

\begin{tabular}{|l|c|c|c|c|c|c|}
\hline Jenis Proses & T1 & T2 & T3 & T4 & Jumlah & Persentase \\
\hline Material & 28 & 52 & 37 & 44 & 161 & $54.03 \%$ \\
\hline Relasional & 22 & 11 & 19 & 17 & 69 & $23.15 \%$ \\
\hline Mental & 3 & 5 & 3 & 0 & 11 & $3.69 \%$ \\
\hline Taingkah laku & 3 & 2 & 1 & 2 & 8 & $2.68 \%$ \\
\hline Wujud & 12 & 6 & 10 & 5 & 33 & $11.07 \%$ \\
\hline Verbal & 3 & 5 & 3 & 5 & 16 & $5.37 \%$ \\
\hline Jumlah proses tiap buku & 71 & 81 & 73 & 73 & 298 & $100 \%$ \\
\hline
\end{tabular}




\section{Unsur Sirkumstan}

Sirkumstan dapat difinisikan sebagai lingkungan, sifat, atau lokasi tempat berlangsungnya suatu proses. Sirkumstan dalam tata bahasa tradisional lazim dikenal dengan fungsi keterangan. Unsur Sirkumstan yang terdapat di dalam keempat buku teks pelajaran tersebut dapat dilihat pada tabel berikut.

Tabel 2. Unsur Srikumstan

\begin{tabular}{|c|c|c|c|c|c|c|c|}
\hline \multicolumn{2}{|c|}{$\begin{array}{l}\text { Jenis } \\
\text { Sirkumstan }\end{array}$} & \multirow{2}{*}{$\begin{array}{l}\text { T1 } \\
2 \\
\end{array}$} & \multirow{2}{*}{$\begin{array}{l}\text { T2 } \\
0\end{array}$} & \multirow{2}{*}{$\begin{array}{l}\text { T3 } \\
0 \\
\end{array}$} & \multirow{2}{*}{\begin{tabular}{l|}
$\mathbf{T 4}$ \\
1 \\
\end{tabular}} & \multirow{2}{*}{$\begin{array}{l}\text { Jumlah } \\
3 \\
\end{array}$} & \multirow{2}{*}{$\begin{array}{l}\text { Persentase } \\
1.16 \% \\
\end{array}$} \\
\hline Rentang & Waktu & & & & & & \\
\hline & Tempat & 2 & 2 & 4 & 0 & 8 & $3.10 \%$ \\
\hline \multirow[t]{2}{*}{ Lokasi } & Waktu & 8 & 15 & 10 & 17 & 50 & $19.38 \%$ \\
\hline & Tempat & 13 & 21 & 36 & 16 & 86 & $33.33 \%$ \\
\hline \multicolumn{2}{|l|}{ Cara } & 5 & 27 & 16 & 7 & 55 & $21.32 \%$ \\
\hline \multicolumn{2}{|l|}{ Sebab } & 1 & 9 & 8 & 7 & 25 & $9.69 \%$ \\
\hline \multicolumn{2}{|l|}{ Penyerta } & 1 & 8 & 7 & 2 & 18 & $6,98 \%$ \\
\hline \multicolumn{2}{|l|}{ Peran } & 2 & 1 & 2 & 0 & 5 & $1,94 \%$ \\
\hline \multicolumn{2}{|l|}{ Masalah } & 2 & 1 & 3 & 2 & 8 & $3,1 \%$ \\
\hline \multicolumn{2}{|l|}{ Jumlah } & 36 & 84 & 86 & 86 & 258 & $100 \%$ \\
\hline
\end{tabular}

Melihat unsur sirkumstan yang terdapat pada tiap-tiap teks pelajaran, sirkumstan lokasi tempat dan cara lebih mendominasi isi teks. Hal ini menunjukkan bahwa teks pelajaran yang dijadikan sebagai materi pembelajaran pada keempat buku ini lebih menekan dimana letak keberadaan atau asal suatu hal apa yang dibahas. Sedangkan sirkumstan cara dipergunakan untuk menjelaskan cara melakukan kegiatan atau kreativitas.

\section{Pola Pengembangan Tema-Rema Teks Pelajaran}

Dalam interaksi alamiah, pembicara atau penulis cenderung menggunakan kombinasi pola pengembangan Tema-Rema. Pola pengembangan satu pola secara terus menerus membuat kebosanan dan melawan sifat kealamiahan teks. Dengan kalimat lain, secara alamiah variasi pemakaian pola pengembangan Tema-Rema digunakan dalam pemakaian bahasa.

Pola pengembangan Tema-Rema perlu dilihat dalam teks pelajaran siswa yang terdapat dalam buku teks yang digunakan sebagai buku pegangan siswa. Wujud pola pengembangan tema yang terdapat di dalam teks pelajaran siswa SD kelas IV dalam buku teks pelajaran Kurikulum 2013, penulis dapat melihat bahwa pengembangan tema teks pelajaran yang ditulis secara bervariasi.

Berdasarkan data yang dianalisis, ditemukan bahwa klausa pada teks pelajaran tidak menggunakan satu pola tertentu atau tunggal dalam pengembangan teks yang dijadikan materi pembelajaran. Dengan kalimat lain, dalam satu teks terdapat lebih dari satu pola pengembangan Tema-Rema. Misalnya, klausa pertama sampai dengan klausa keempat menggunakan pola tetap, sedangkan klausa kelima sebagai pengembangan dari klausa kedua.

Tiga pola pengembangan tema yang ada di dalam teks pelajaran, terdiri atas pola zig-zag, pola tetap (re-interartion), dan pola gabungan (mulitipe). Berikut akan dipaparkan pola pengembangan Tema-Rema teks pelajaran yang digunakan oleh siswa dalam buku teks kurikulum 2013.

\section{Pola Zig-Zig}

Pengembangan pola Tema-Rema dengan menggunakan pola Zig-zag lebih sering melakukan pengulangan kata dan frase yang sama guna membentuk kohesian antarklausa dalam sebuh teks pembelajaran. Artinya, dengan adanya pola pengembangan ini dalam teks pembelajaran tidak memungkin adanya informasi baru yang di luar pembahasan klausa sebelumnya. Hal ini dapat dilihat pada data teks "ayo belajar" (T3.2) pada $\mathrm{Kl}(1)$, (2), dan $\mathrm{Kl}(3)$.

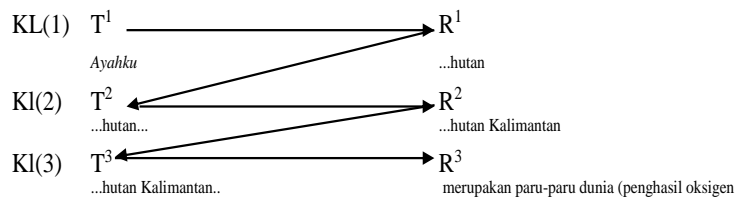


Berikut ini contoh klausa yang pola pengembangannya menunjukkan wujud pola zig-zag pada teks pelajaran "ayo belajar" T3.2 Pada Kl(1) sampai Kl(3), yang menjadi tema pada ketiga klausa di bawah ini, yaitu frase yang dimiringkan.

\section{Kl(1) Ayahku mendapatkan kayu untuk bahan baku mebel dari hutan \\ $\mathrm{Kl}(2) \quad$ Salah satu hutan di Indonesia yang sering diambil pohonnya adalah hutan Kalimantan \\ $\mathrm{Kl}(3)$ dahulu, hutan Kalimantan sangat lebat merupakan paru-paru dunia (penghasil oksigen)}

Berdasarkan pola pembentuk TemaRema teks pelajaran tersebut dapat dilihat kohesian diwujudkan dengan pengulangan kata dan frase yang sama. Seperti terlihat $\mathrm{Kl}(1)$, Rema Kl tersebut terdapat kata hutan, yang diulang kembali pada Tema $\mathrm{Kl}(2)$. Selanjutnya, Rema Kl(2) terdapat frase hutan Klimantan, yang disebutkan kembali pada Tema Kl(3).

\section{Pola Tetap (re-interartion)}

Pola pengembangan ini dapat ditemukan pada teks pembelajaran, "tahukah kamu" (T1.1), "ayo belajar" T3.2, "ayo cari tahu" (T3.6). Dapat dilihat pada data teks tersebut, strategi penulis untuk membentuk pola ini menggunakan kata, frase yang sama dan menggunakan kata lain, seperti kata pronomina.

Berikut ini contoh teks yang menunjukkan pola tetap (re-interation), seperti terlihat pola pengembangan TemaRema Kl(1), (2), (3), dan (4) pada teks pelajaran "ayo belajar" T3.2.

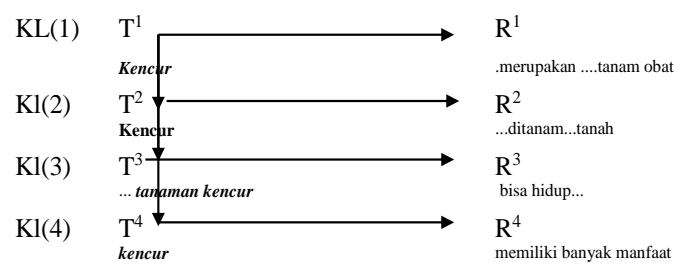

Di bawah ini kutipan teks yang menunjukkan pola pengembangan tersebut. Teks di bawah ini klausa yang menunjukkan Tema, yakni frase atau kata yang dimiringkan, sedangkan frase yang lainnya termasuk Rema teks.

(1) Kencur merupakan salah satu jenis tanaman obat

(2) Kencur sangat mudah ditanam dengan permukaan tanah

(3) Maka, tanaman kencur ini bisa hidup dengan mudah.

(4) Kencur memiliki banyak manfaat mengobati berbagai macam penyakit, seperti influenza pada bayi, masuk angin, sakit kepala, batuk, dan keseleo.

Dengan memahami pola pengembangan teks T3.2 tersebut, dapat dijelaskan bahwa kemunculan $\mathrm{Kl}(2)$, (3), dan (4) pada teks pelajaran ini, mengikuti pola pengembangan pola tetap (re-iteration). Kemunculan $\mathrm{Kl}(2)$ merupakan penjelasan tema pada $\mathrm{Kl}(1)$. Penjelasannya dengan mungulangi kembali kata kencur yang terdapat pada tema $\mathrm{Kl}(1)$. Begitu juga seterusnya dengan kemunculan tema $\mathrm{Kl}(3)$ dan $\mathrm{Kl}(4)$.

\section{Pola Gabungan (Multiple)}

Pola ini merupakan pola yang paling banyak ditemukan pada teks pembelajaran. Berdasarkan data yang ada, pola pengembangan beberapa Tema atau Rema sebuah klausa dapat memunculkan rincian informasi dengan menggunakan klausa lainnya, serta klausa baru yang muncul juga menimbulkan terbentuknya Tema dalam klausa baru. Sehinga pola ini lebih efektif digunakan guna menjelaskan informasi berupa materi pembelajaran dengan lebih rinci. Beberapa contoh pola ini dapat ditemukan pada data, 'tahukah kamu' (T4.1), 
"ayo cermati" (T4.4) "ayo bekerja sama" T4.5.

Pola pengembangan jenis ini dapat ditemukan pada teks pelajaran "ayo bekerja sama" T4.5. Klausa yang dibentuk dengan cara ini pada teks tersebut, yakni $\mathrm{Kl}(3)$, sampai dengan $\mathrm{Kl}$ (7).

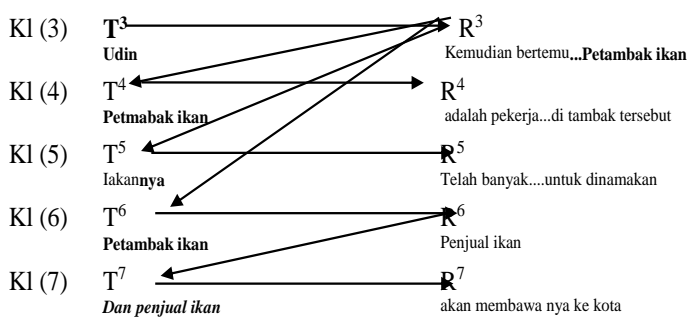

Untuk lebih jelas gambarannya, berikut ini akan kutipan teks yang menunjukkan $\mathrm{Kl}(3)$, sampai dengan $\mathrm{Kl}(7)$ pada teks pelajaran "ayo bekerja sama" menunjukkan adanya pola gabungan.

(1) Udin kemudian bertemu dengan seorang Petambak Ikan

(2) Petambak ikan adalah pekerja yang pekerjaannya membuat tambak/kolam dan memelihara ikan untuk dikembangkan di tambak tersebut.

(3) Jika jumlah ikannya telah banyak dan cukup besar untuk dimakan

(4) Petambak ikan akan menjual ikanikannya kepada penjual ikan

(5) Dan penjual ikan akan membawanya ke kota

Dapat dilihat dari pengembangan pola Tema-Rema teks tersebut, dapat dijelaskan, bahwa $\mathrm{Kl}(4)$, (5), dan (6) dikembangkan dari Rema Kl(3), dengan realisasikan dengan cara menggunakan secara berulang frase Petambak ikan yang terdapat pada Rema Kl(3). Selanjutnya Tema Kl(5) menggunakan pronominal -nya yang merujuk juga pada frase petambakan ikan pada Rema $\mathrm{Kl}(3)$. Begitu juga halnya dengan munculnya $\mathrm{Kl}(6)$ sebagai penjelas dari Tema pada $\mathrm{Kl}(1)$.
Namun, akan berbeda dengan Tema yang terdapat $\mathrm{Kl}(7)$, yang muncul sebagai penjelasan lanjutan dari Tema pada $\mathrm{Kl}(6)$, dengan mengulang kembali frase penjual ikan.

Pola pengembangan gabungan pada teks ini, mengarahkan pembaca untuk mengetahui informasi terkait dengan profesi yang menghasilkan ikan, yakni petambkan ikan. Penjelasan ini terdapat pada $\mathrm{Kl}(4)$. Serta kapan mereka memanen ikan yang mereka pelihara dijelaskan pada $\mathrm{Kl}(3)$. Selanjutnya $\mathrm{Kl}(4)$ menjelaskan kemana petambak ikan akan menjual hasil tambaknya. Terakhir $\mathrm{Kl}(5)$ merupakan pengembangan dari Tema $\mathrm{Kl}(4)$, yang menjelaskan kemana penjual ikan membawa hasil panen para petembak ikan.

\section{Relevansi Isi Teks Pelajaran terhadap Kompetensi Dasar (KD) Kurikulum 2013}

Berdasarkan hasil penganalisisan kerelevansi isi teks pelajaran dengan $\mathrm{KD}$ dalam kurikulum 2013 ditemukan beberapa teks pelajaran yang tidak memiliki kerelevansian. Berikut ini akan dipaparkan beberapa teks pelajaran yang tidak memiliki kerelevansian tersebut.

\section{Teks pelajaran "Tahukah kamu" (T1)}

Berdasarkan hasil analisis transitivitas yang ada dalam teks pelajaran ini terdapat beberapa entitas yang ada di dalam teks ini yang menunjukkan hal yang dibahas, di antaranya berupa rumah panjanag, keunikan rumah ini, kepala keluarga, rumah unik seprti ini, bangunan, rumah lontik, bentuk atap, melengkung, mering dan lain-lain. Dengan memahami adanya unsur tersebut dapat dinyatakan bahwa, isi teks materi pembelajaran ini membahas tentang wujud kebudayaan yang ada di Nusantara yang berupa jenis-jenis rumah adat tradisonal. 
Teks materi pembelajaran ini jika dilihat berdasarkan segi fungsi, yakni digunakan sebagai materi pembelajaran Bahasa Indonesia, Matematika, dan Seni Budaya dan Prakarya (Sbdp). Dari ketiga jenis mata pelejaran ini, mata pelajaran Bahasa Indonesialah yang tidak relevan. Dikatakan demikian karena kompetensi dasar (KD) dalam kegiatan pembelajaran bahasa Indonesia pada sub pembelajaran "tahukah kamu" yang dimiliki ada dua KD, yaitu (1) menggali informasi dari teks laporan hasil pengamatan tentang gaya, gerak, energi panas, bunyi, dan cahaya dengan bantuan guru dan teman dalam bahasa Indonesia lisan dan tulis dengan memilih dan memilah kosakata baku (2) mengamati, mengolah, dan menyajikan teks laporan hasil pengamatan tentang gaya, gerak, energi panas, bunyi, dan cahaya dalam bahasa Indonesia lisan dan tulis dengan memilih dan memilah kosakata baku. Dapat dilihat dari kedua KD tersebut, teks pelajaran yang membahas tentang jenis rumah tradisonal tidak memiliki keterkaitan dengan kedua KD yang harus dicapai oleh siswa dalam sub pembelajaran ini.

\section{Teks pelajaran "Tahukah kamu" (T2)}

Teks pelajaran ini berdasarkan penyusunan di dalam buku bertema "Berhemat Energi" digunakan untuk mencapai KD pada mata pelajaran Bahasa Indonesia, IPA, dan SBdP. Dengan memahami dari segi unsur transtivitas yang ada di dalamnya, materi pembelajaran menuntut adanya suatu kreativitas siswa dalam membuat kincir angin dari bahan kertas dan plastik. Jika isi teks ini dikaitkan dengan ketiga KD mata pelajaran hanya memiliki relevansi dengan KD mata pelajaran SBdP, yaitu (1) Mengetahui berbagai alur cara dan pengolahan media karya kreatif, dan (2) Membuat karya kreatif yang diperlukan untuk melengkapi proses pembelajaran dengan memanfaatkan bahan di lingkungan. Dengan kalimat lain, teks pelajaran ini tidak bisa digunakan untuk memenuhi KD mata pelajaran Bahasa Indonesia dan IPA.

\section{Teks pelajaran "Ayo menulis" (T3)}

Berdsarkan hasil analisis transitivitas dalam teks ini membicarakan tentang jenis paragraf deskriptif. Hal ini dapat ditunjukkan dengan adanya partisipan bentuk berupa kata paragraf deskriptif. Jika, dilihat KD yang akan dicapai pada kegiatan menulis ini, siswa dituntut untuk mampu menggali informasi dari teks laporan hasil pengamatan tentang gaya, gerak, energi panas, bunyi, dan cahaya dengan bantuan guru dan teman dalam bahasa Indonesia lisan. Maka, penjelasan terkait dengan paragraf deksripsi tidak memiliki keterkaitan dengan KD yang dicapai, sehingga dapat dikatakan bawah teks pemebelajaran ini tidak memiliki relevansi dengan KD yang akan dicapai.

\section{SIMPULAN}

Analisis teks dengan pendekatan Linguistik Fungsional Sistemik terhadap teks pelajaran dalam buku teks pelajaran siswa SD kelas IV kurikulum 2013, bertema "indahnya kebersamaan", "Behemat Energi", "Peduli Terhadap Lingkungan", dan "Bebagai pekerjaan" menghasilkan beberapa temuan sebagai simpulan analisis.

Berdasarkan hasil analisis transitivitas, unsur proses yang lebih dominan adalah proses material sebanyak $54.03 \%$. Hal ini menunjukkan teks pembelajaran ini lebih menekankan pada hal-hal yang bersifat kongkret. Sedangkan unsur sirkumstan, yang lebih dominan sirkumstan lokasi tempat sebanyak $33.33 \%$ dan sirkumstan cara sebanyak $21,32 \%$.

Pola pengembagan Tema-Rema pada teks pelajaran memiliki fungsi informatif dengan menggerakan kesadaran siswa mampu mehami materi pembelajaran yang 
berupa fakta, konsep, dan teori. Dengan demikian kreativitas pengarang/penulis teks dituntut untuk mampu memberikan informsis tersebut lebih rinci dan jelas kepada siswa. Sehingga di dalam teks pelajaran ini terdapat beberapa pola pengembangan teks yang bisa ditemukan. Pola pengembangan Tema-Rema pada keempat buku teks pelajaran ini beberapa mengikuti pola pengembangan, pela Zig-zag, pola Tetap, dan pola Gabungan.

Melihat bentuk relevansi isi teks pelajaran dengan kurkulum 2013, dilakukan dengan cara melihat katerkaitan isi teks dengan KD yang akan dicapai. Dari hasil analisis, beberapa teks pembelajaran yang tidak memiliki relevanasi dengan KD pada kurkulum 2013. Maka buku ini perlu dilakukan tinjauan ulang dan dilakukan revisi terhadap teks yang dijadikan sebagai materi pembelajaran yang terdapat di dalamnya.

\section{DAFTAR PUSTAKA}

Adisaputra, Abdurahman. 2008. Linguistik Fungsional Sistemik: Analisis Teks Materi Pembelajaran di Sekolah Dasar (SD). Jurnal Logat, 4 (1): 12-21.

Bloor, Thomas \& Bloor, Meriel. 2004. The Functional Analysis of English: A Hallidayan Approach. London: Arnold.

Butcher, Judith. 1988. Penyuntingan Naskah Buku Pegangan Cambridge. Penerjemah:Salindinah Sutarto. Jakarta: Balai Pustaka.

Djajasudarma, T.F. 2006. Wacana: Pemahaman dan Hubungan Antarunsur. Bandung: Rafika Aditama.
Eggins, Suzanne. 2004. An Introduction to Systemic Functional Linguistics (2nd Edition). London: Continuum.

Eneste, Pamasuk. 2005. Buku Pintar Penyunting Naskah. Jakarta: Gramedia Pustaka Utama.

Halliday, M.A.K. \& Matthiessen, Christian. 2004. An Introduction to Functional Grammar 3rd)edition). London: Arnold.

Halliday, M.A.K. 1994. An Introduction to Funcional Grammer. London: Edward Arnold.

Halliday, M.A.K \& Hasan, R. 1992. Bahasa Konteks, dan konteks: aspek-aspek bahasa dalam pandangan semiotik sosial. Yogyakarta: Gadja Mada University press.

Halliday, M.A.K \& Fawcett, P Robin. 1987. New Developments In Systemic Linguistics. London: Frances Pinter.

Halliday, M.A.K. 2007. Language and Education. London: Continuum

Halliday, M.A.K \& Hasan, R. 1976. Cohesion In English. London: Longman.

Halliday, M.A.K. 1978. Language as Social Semiotic: The Social Interpretation of Language And Meaning. London: Edward Arnoldo.

Hidayat, A.A. 2009. Filsafat Bahasa: Mengungkap Hakikat Bahasa Makna dan Tanda. Bandung: Remaja Rosdakarya.

Hoed, Benny H. 2011. Semiotik dan Dinamika Sosial Budaya (2nd edition). Jakarta: Komunitas Bambu. 